\title{
Ensiling for anaerobic digestion (AD): a review of key considerations to maximise methane yields
}

\author{
Raffaella Villa ${ }^{a *}$ Lelia Ortega Rodriguez ${ }^{b}$, Cecilia Fenech $^{b}$, Ogemdi Chinwendu Anika $^{c}$ \\ a De Montfort University, Institute of Energy and Sustainable Development, Leicester, LE1 9BH. \\ ${ }^{b}$ Cranfield University, School of Water, Energy and Environment, Cranfield, MK430AL, UK \\ ${ }^{c}$ Department of Microbiology, Faculty of Biological Sciences, University of Calabar, Nigeria
}

\section{Abstract}

Growth in anaerobic digestion (AD) has expanded the use of silage to preserve crops intended for renewable energy generation. Preservation of seasonal crops and their residues is critical in a process that needs continuous feeding. Whilst the impact of different crops and harvesting times on methane formation is relatively well understood, to date the specific considerations for maximising methane yields through management practice have been largely ignored. The present paper reviews the current state of knowledge on silage practice for biogas production and specifically on the factors affecting methane yields of ensiled crops, as well as their influence on the silage quality, and provides suggestions for further research in the field. Data shows that ensiling is able to conserves $93 \%$ of crops gross energy when good practices are followed. Shorter chop length (7-10 mm), lower DM feedstock (20-35\%) and lower compaction values (less than $250 \mathrm{~kg} / \mathrm{m3}$ ) are used to achieve higher biogas yields. Increase biogas production can also be obtained by managing the organic acids production with the preferential formation of acetic acid and ethanol instead of lactic acid via enzymatic or microbial additives. The review outcomes show that more research is required to provide a clear-cut distinction between the requirements for ensiling crops for $A D$ versus crops for animal feed.

\section{Highlights}

- Higher biogas achieved with lower DM feedstock and lower compaction values

- Shorter chop length produced higher biogas yields

- Increased biogas yields obtained with additives and a wider range of acids

- Research need for specialised silage bioadditives targeted at biogas production

- Silage of agricultural residues needs a different approach

\section{Keywords}

Biogas, methane yield, dry matter, quality silage, storage systems

\section{List of abbreviations}

VS: Volatile solids

DM: Dry matter

LAB: lactic acid bacteria

WSC: water soluble carbohydrates

*Corresponding Author: Email: raffaella.villa@dmu.ac.uk Tel:++44(0)1163664257 


\section{Introduction}

Energy crops produce some of the highest biogas yields as compared to other feedstocks [1] and have for some time now increased the AD (AD) feedstock base [2]. This growth has expanded the use of silage, traditionally used for preserving crops for animal feed, to crops intended for renewable energy generation $[3,4]$. Preservation of seasonal crops and their residues is critical in a process that needs continuous feeding $[5,6]$. However, for animal feed the main objective of silage is to preserve crops nutritive value, whilst minimising methane production in the animal rumen. Whereas, in anaerobic digestion the silage process should be focused on preserving the crops for achieving the highest methane yields possible $[7,8]$. Crops methane yield $\left(\mathrm{m}^{3} \mathrm{CH}_{4}\right.$. ha-1) depends primarily upon the biomethane potential $\left(\mathrm{m}^{3} \mathrm{CH}_{4}\right.$. $\mathrm{t}^{-1}$ ) of the feedstock (e.g. its composition) and the biomass yield (t. ha ${ }^{-1}$ ) [9]. Both of these parameters can be influenced by different factors throughout the feedstock chain such as cultivation, harvest and storage methods [9-11]. Whilst the impact of different crops and harvesting times on methane formation is relatively well understood $[2,9,10]$ to date the specific considerations for maximising methane yields through silage management practice have been largely ignored. The present review consolidates the current state of knowledge and highlights areas of future research in relation to silage practice for biogas production. Maximum methane yields can be achieved with high-quality silage abut different crops might require different storage management practice $[7,8]$. In addition, silage of agricultural waste should be taken into consideration to couple renewable biogas production and sustainable waste management. The review will focus on four energy crops: maize, grass, whole crop cereals and beet, which are the dominating energy crops used in the UK $[3,12]$. Specifically, an in-depth review of the current understanding of the factors that affect the energy yields of ensiled crops, as well as the influence of key parameters on the silage quality such as characteristics of the crop at ensiling, silo design and silage management, in addition to silage of agricultural waste. Finally, a number of gaps in research related to silage for AD will be identified and recommendations for future studies proposed. Up to date references on biogas production from silage crops focus on the biogas yields of material rather than the management and storage conditions of the feedstock. To the best of our knowledge this is the first review that focuses on crop ensiling for energy production, with specific focus on management practices for maximising methane yields.

\section{Ensiling for Anaerobic Digestion}

Ensiling consists of various biochemical processes, each of which directly or indirectly affects biogas production by changing the properties of the feedstock $[13,14]$. The process functions through the production of organic acids, such as lactic and acetic acid, which reduce the $\mathrm{pH}$ of the feedstock causing its preservation against the growth of fungi, bacteria and yeasts [15]. There are four phases that occur during silage fermentation: an initial aerobic phase, followed by a lag phase and an anaerobic phase. At the end of the anaerobic phase the ensiling process has been largely concluded, thus leading to the stable phase, which lasts until the silage is 
required for use and the feed-out phase starts $[5,16]$. It is important that all four phases are well-understood to minimise potential reductions in biogas yields (Figure 1A). The aerobic phase occurs during the chopping, filling, and packing steps $[5,17]$. During this phase, oxygen is eliminated as a result of respiration. Respiration is a 'wasteful' process during which aerobic microorganisms uptake sugars competing with lactic acid bacteria (LAB) and the AD anaerobic bacteria. Therefore, aerobic processes causes losses of energy and dry matter (DM) $[5,16]$. Figure $1 \mathrm{~B}$ provides a summary of mass and energy recovery depending on the microbial groups abovementioned.

The anaerobic phase (or fermentation phase) is dominated by homofermentative or heterofermentative $\mathrm{LAB}$ which produce a drop in $\mathrm{pH}$, from 5.0 to 3.7 due to increasing lactic acid concentrations $[5,18]$. At this $\mathrm{pH}$ level the growth of harmful microorganisms, mainly enterobacteria, clostridia and yeasts, is inhibited, energy losses are limited in both cases whereas biomass recovery is lower if heterofermentative bacteria are able to thrive (first three set of bars in figure 1B) $[16,19,20]$.

The stable phase starts when the growth of LAB stops $[5,18]$. At this point, the LAB are dominant and lactic acid is the predominant end-product formed. If the silo is properly sealed, DM and energy losses in this phase should be minimal as no additional changes should be taking place $[5,20,21]$.

(A)

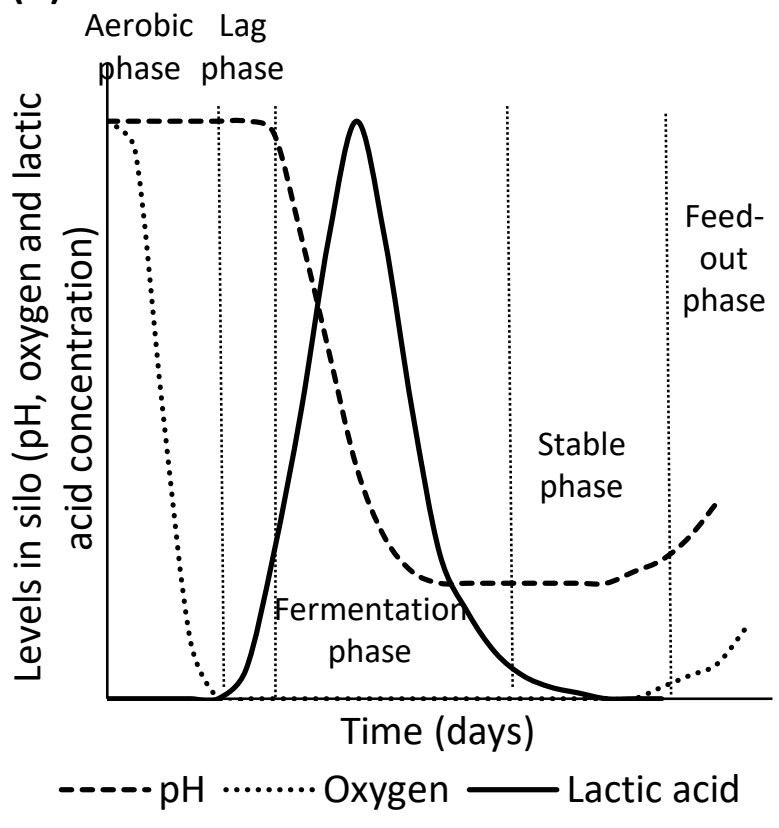

(B) $\quad$ D Dry matter $\quad \square$ Energy

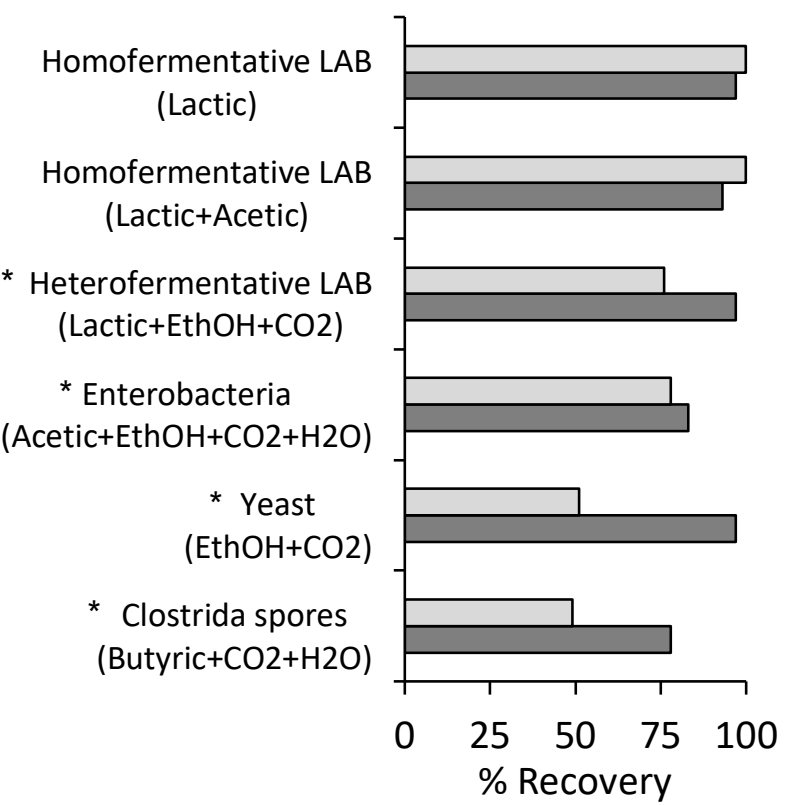

Figure 1. A. Changes during ensilage fermentations of $\mathrm{pH}$, oxygen and lactic acid (modified from [16]). B. Mass and energy recovery from fermentation during ensiling. (adapted from [25]). * Undesirable pathways for animal feed 
The feed-out phase begins when the silo is opened and continues until all the silage has been removed and fed into the AD plant $[5,19]$. During this final phase, the ensiled crop face is exposed to oxygen, which supports yeast growth. At the same time, the silage $\mathrm{pH}$ increases, allowing previously inhibited fungi and bacteria to produce different fermentation products, with dry matter losses up to $50 \%[17,21]$ and reduce silage quality for animal feed $[5,21]$. However, as figure 1B clearly demonstrates, this is not necessarily the case for energy production (bottom set of bars in figure 1B), where the presence of other acids then lactic can be beneficial to biogas production and the AD process $[19,22,23,24]$. Butyric acid, higher volatile fatty acids and alcohols are associated with high theoretical methane yields based on their elemental composition $[11,24]$.Consequently, silage that was traditionally considered to be poor output for animal feed may be good $A D$ feedstock and reach higher methane potentials.

Ensiling has been reported to increase methane yields as compared to fresh matter, based on volatile solids (VS) [10,26-32]. However, there are a number of studies showing no significant differences in methane yields between ensiled and fresh crops [32,25].

Figure 2 shows the impact of ensiling energy crops without additives on methane production using the published data of comparative studies between silage and fresh material $[10,11,20,25,27,29-31,33]$ (Table 1S). A paired two tailed t-test used to evaluate the significance of the difference between biogas from silage and from the same fresh material showed that, although silage produced slightly more biogas than the fresh material, the difference between the two data sets was not significant $(p=0.224)$. Several authors reported that some fermentation products have the potential to enhance methane yield of silage crops, especially those derived from undesirable microbial activity $[19,20,26]$.

Notwithstanding this, the methane yield of silage crops $\left(\mathrm{m}^{3} \mathrm{CH}_{4} . \mathrm{ha}^{-1}\right)$ does not only depend on the methane potential of the feedstock, it also takes into consideration the field biomass yield (t. ha ${ }^{-1}$ ) [9].. When considering silage for biogas production it is important to compare methane yield per hectare, because DM losses due to the formation of undesirable organic acids may be compensated by improved crop digestibility [34]. For example, fresh beets showed less biogas potential than other cereal and forages. However, after ensiling, beets showed better biogas potential and methane yields than other crops due to the increasing ethanol formation during ensiling Weissbach (2009).

The effect of storage time on methane yields has also been studied by [11,29,31,35]. All four studies reported that longer storage periods have a positive effect on methane yield. This is attributed to the fact that in well preserved silage the concentration of ethanol increases as a function of the age of silage $[31,36]$. An analysis of the data reported in figure 2 showed that these improvements were not significant. Of note is that, some researchers have stated that storage requirements may not be as stringent when using silage for $A D$ as compared to when using silage for animal feed [37]. This is because factors of importance in animal nutrition, such as protein content, digestibility, palatability or DM intake, have little consequence in $A D$, 
where preservation of energy during storage is the main concern. In fact, ensiling has been shown to conserve $93 \%$ of the crops gross energy when good practices are followed [38]. On the other hand, poor silage management practices in all phases have been associated with energy losses as high as $40 \%$ [38]. However, there is a dearth of information about the degree of dependence between well preserved silage and methane yield and further studies are required to fully understand the link that exists $[7,39,40]$.

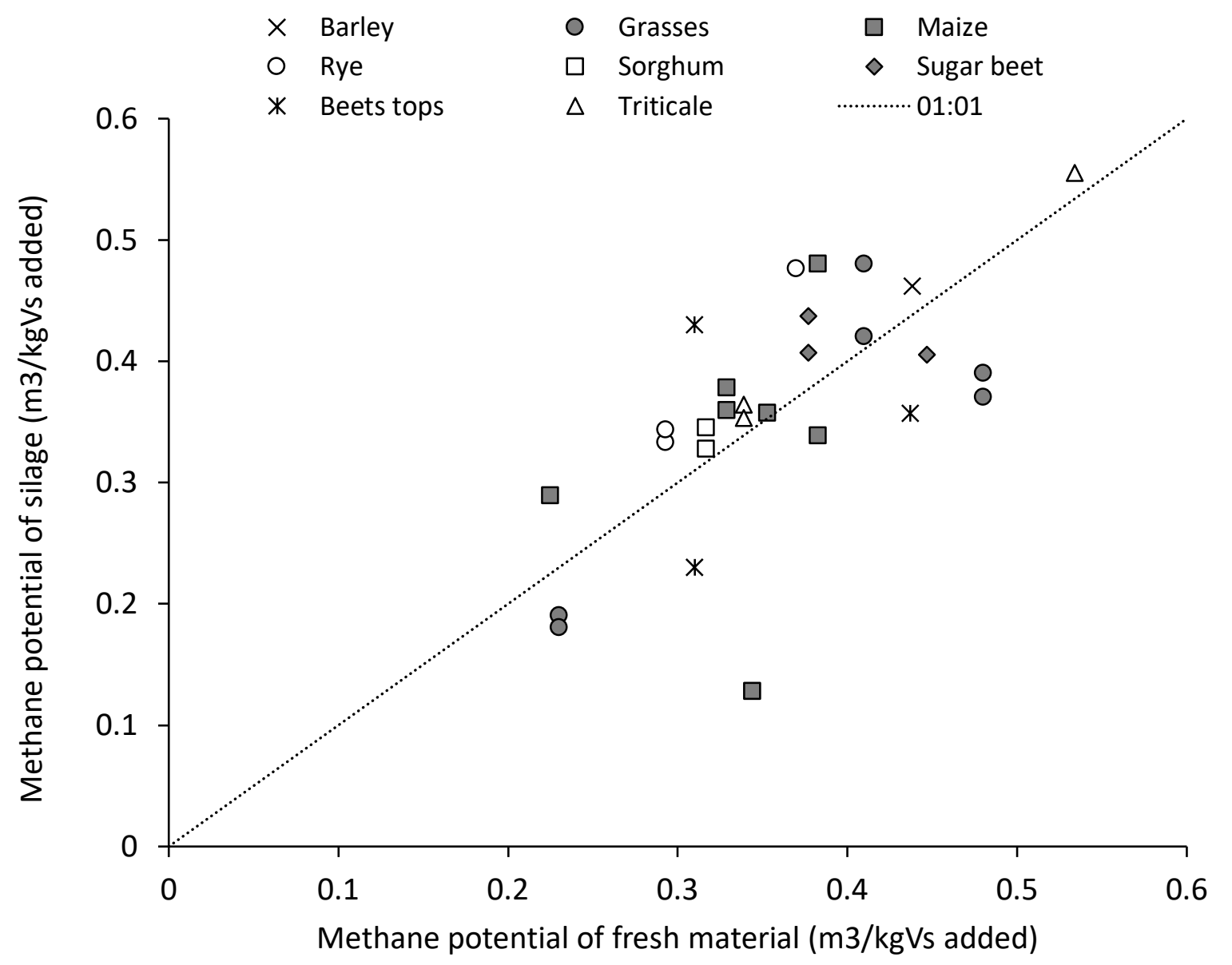

Figure 2. Impact of ensiling without additives on methane formation of maize, grasses beet tops, barley, rye, triticale, sorghum, sugar beets an beets with different storage times (from 3 to 12 months) [10,11,20,25,27,29-31,33]. Data used for the table are available in supplementary material (T1S).

\section{Key considerations to maximise silage methane yields}

The primary objective in preserving crops for biogas production is to prevent energy losses during storage [13]. The specific characteristics of good quality silage will depend upon the specific crop being ensiled whilst the amount of losses and the final silage quality will be 
influenced by a number of factors, including: fermentation profile, moisture content and chop length of the feedstock, use of additives, silo style and silo management.

\subsection{Fermentation profile}

Data reported in table 1 outlines silage fermentation profiles found in literature to obtain proper preservation of maize, grass, whole crop cereal and beet for animal feed and biogas production. There are some considerable differences in target values between the various crops listed, which indicate the importance of determining crop specific targets, rather than universal targets. The $\mathrm{pH}$ is usually lower for materials with higher water content. A faster $\mathrm{pH}$ decrease will produce more water soluble carbohydrates in the silage mass and therefore more biogas [41]. Higher lactic acid levels indicate good fermentation and lead to better preservation for animal feed. Whereas lower levels indicate the silage was not harvested at the proper moisture content, chopped to incorrect length, not well packed or exposed to oxygen, optimal for biogas production. High concentration of acetic acid may indicate the silage was not packed densely or quickly enough, was not covered appropriately, or was too dry, not ideal for animal feed but good for biogas production. High level of acetic acid can also be produced by additives (hetero LAB) and produce higher biogas yields [42, 43] . Similarly, high levels of butyric acid, which indicate clostridia fermentation, are not recommended for animal feed but can be good for energy production $[41,44]$. The theoretical $\mathrm{CH}_{4}$ content (expressed as a proportion of biogas volume) of butyric acid, propionic acid and ethanol are $0.63,0.58$ and 0.75 respectively [45]. Hence increased concentrations of compounds like ethanol [46] and butyric [44] are able to produce higher specific $\mathrm{CH}_{4}$ yield.

\subsection{Moisture Content}

Crops for biogas production are usually harvested at a less mature stage of growth than for animal feeding since the content of lignocellulose, which is not easily degraded by anaerobic processes, increases with time [33]. In general, it could be said that moist material is preferred for the anaerobic digestion process [33,42]. When harvested crops, like grass, have higher moisture content than is desirable, the cut material is left in the field in order for it to wilt. Table 1 compares the dry matter content suggested in the literature for crops for biogas production and animal nutrition.

From a technical point of view, lower DM contents (below 25-30\%) lead to formation and release of silage effluent associated with additional mass [60] and energy losses [8].This can be counteracted by collecting and reusing leachate for biogas production [60]. High DM contents, on the other hand, can hinder sufficient compaction of the crop material within the silo and promote aerobic deterioration at feed-out [60] or cause a negative impact upon storage stability [50]. 
Table 1. Target values of fermentation characteristics $[6,8,11,21,23,29,33,41,45,47-59]$.

\begin{tabular}{|c|c|c|}
\hline & $\begin{array}{l}\text { Silage for biogas } \\
\text { production }\end{array}$ & $\begin{array}{l}\text { Silage for animal } \\
\text { feed }\end{array}$ \\
\hline \multicolumn{3}{|c|}{ Organic acid/alcohol range (g/kgDM) } \\
\hline \multirow{5}{*}{ Maize } & Lactic 19-63 & Lactic $40-70$ \\
\hline & Acetic $16-39$ & Acetic $10-30$ \\
\hline & Butyric 1.3-45 & Butyric $<1.3$ \\
\hline & Ethanol $12-20$ & Ethanol N/A \\
\hline & pH 3.8-4.2 & $\mathrm{pH}<4.2$ \\
\hline \multirow{5}{*}{ Grass } & Lactic 30-50 & Lactic $80-120$ \\
\hline & Acetic $20-50$ & Acetic $20-50$ \\
\hline & Butyric 1-8 & Butyric $<10$ \\
\hline & Ethanol 7-16 & Ethanol N/A \\
\hline & $\mathrm{pH} 4.5$ & $\mathrm{pH}<4.5$ \\
\hline \multirow{5}{*}{ Whole crop cereal } & Lactic 20-55 & Lactic 30-60 \\
\hline & Acetic $16-39$ & Acetic $10-30$ \\
\hline & Butyric 1.3-11 & Butyric $<3$ \\
\hline & Ethanol 12-31 & Ethanol N/A \\
\hline & $\mathrm{pH} 3.8-4.0$ & $\mathrm{pH}<4.2$ \\
\hline \multirow{5}{*}{ Beet } & Lactic 9-52 & Lactic $>30$ \\
\hline & Acetic $10-60$ & Acetic $<15$ \\
\hline & Butyric 0-4 & Butyric $<0.2$ \\
\hline & Ethanol 28-48 & Ethanol N/A \\
\hline & pH 3.7-3.8 & $\mathrm{pH}<4.0$ \\
\hline
\end{tabular}

DM range (\%)

\begin{tabular}{lcc}
\hline Maize & $27-31$ & $30-35$ \\
\hline Grass & $26-30$ & $30-45$ \\
\hline Whole crop cereal & $30-36$ & $33-50$ \\
\hline Beet & $20-23$ & 25 \\
\hline
\end{tabular}

Chop length range $(\mathrm{mm})$

\begin{tabular}{lcc}
\hline Maize & $7-10$ & $12-15$ \\
\hline Grass & $7-11$ & $10-25$ \\
\hline Whole crop cereal & $7-12$ & $20-50$ \\
\hline Beet & $\mathrm{Na}$ & $\mathrm{Na}$ \\
\hline
\end{tabular}

Compaction $\left(\mathrm{kg} / \mathrm{m}^{3}\right)$

\begin{tabular}{lcc}
\hline Maize & 230 & $>400$ \\
\hline Grass & 210 & $>250$ \\
\hline Whole crop cereal & 230 & $>251$ \\
\hline Beet & $\mathrm{Na}$ & na
\end{tabular}


From a biological point of view, clostridia are more sensitive to acidity at a decreasing water activity, thus, a low DM content necessitates a lower $\mathrm{pH}$ of the silage and higher lactic acid formation for inhibition of clostridia [31]. Furthermore, for an effective fermentation during silage making the dry matter content of the crops being ensiled should contain water-soluble carbohydrates (such as sucrose, fructose an, glucose) at an optimal range between 60 and $80 \mathrm{~g} / \mathrm{kg}_{\text {DM }}$ [19]. Biomass containing water-soluble carbohydrates within this range will possess sufficient readily available substrate for fermentation with a corresponding a low buffering capacity for $\mathrm{pH}$ decrease.

A DM content of $28-40 \%$ is often stated as a rough estimate for optimal ensiling conditions. However, it is clear that the critical DM content required to ensure good silage is feedstocks dependent and relates to chemical characteristics such as available water-soluble carbohydrates and buffering capacity [31].

\subsection{Chop Length}

Shorter feedstock chop lengths are considered to be beneficial for preservation because they enhance compaction and oxygen elimination in the silage. For cattle feeding, the feed needs to be long enough to float in the rumen and maintain the rumen fibre, which is an important factor in the prevention of digestive disorders [61]. However, for biogas production a shorter length has a positive effect on the silage degradability in the digester increasing lactic acid fermentation yields [62]. This is because shorter lengths offer a larger surface area for the microorganisms to act upon to break down the crop, thus facilitating biogas production and reduce retention times. The optimal chop length varies depending on the crop ensiled (Table 1) although, there seems to be a minimal value beyond which chopping to shorter sizes will not improve the overall process economy [11]. This is largely related to the increased expenditure associated to the additional energy demand that shorter cuts involve. In fact, it is not yet clear at what level the additional benefit from increased methane yields is eclipsed by the additional cost $[6,62]$. Grass feedstock is particularly controversial and several studies have suggested different chop lengths. For example, studies on a Finnish farm investigated the use of grass chop lengths at 5, 10 and $20 \mathrm{~mm}$ and the grass silage yielded most methane at the $10 \mathrm{~mm}$ size. In contrast, experiments in Germany with grass silage demonstrated higher methane yields when using shorter chopping $(4 \mathrm{~mm})[6]$.

Of note is that in the case of sugar beets, it is suggested that the whole beet is ensiled and then chopped before it is fed into the digester $[60,63]$. This is because chopped beets produce significantly more effluent than whole beets. Therefore, the risk of nutrient losses through uncontrolled effluent is notably increased [63].

\subsection{Additives}

Additives are commonly added during the silage making process, since in field conditions, adequate fermentation conditions are not always guaranteed. A good additive for energy 
crops should enhance the process yields whilst minimising storage losses [34]. The additives most commonly used fall into three classes [13]: (1) Chemical preservatives (e.g. formic acid), which suppress undesirable microbiota, such as Clostridia; (2) Lactic acid bacteria (LAB), which accelerate lactic acid fermentation; and, (3) Molasses, which increase fermentable carbohydrates. Most of these additives (except hetero LAB) have been shown to reduce DM losses during ensiling yet have no significant effect on methane production $[11,29,30,45]$. This makes sense, because when silage is destined for animal feed, in contrast with biogas production, the minimum formation of methane in the rumen is desirable. In fact, in comparing the response of farmers growing crops for $A D$ and animal feeds, none of the $A D$ farmers reported the use of additives, whilst animal feed farmers reported a $25 \%$ usage of additives [64].

Heterofermentative LAB have a positive effect on methane yields [42]. This is attributed to the increased production of acetic acid by the hetero $L A B$, which function as a precursor to methane production $[40,45,48]$. In many cases the additional increase of methane production could be not compensated by the cost of additive application [34]. It is suggested, that a more complex additive with homo and hetero $L A B$ as well as enzymes or bacteria may be the most appropriate for use in silage destined for $A D$ [48]. This is because in addition to increasing lactic acid production they may then later facilitate the hydrolysis process during AD. Yet, further research is required in order to identify the most effective combination for improving methane yields during $A D$.

\subsection{Silo type}

There are several types of silos in use for silage making. Silage clamps, silage bags and wrapped bales are the most commonly used storage systems for both silage that is intended for AD and animal feed. The various types of silo constructions are compared in Table 2. Good quality silage can generally be obtained using any of the systems, as long as the design and management of the silo is appropriate.

In terms of silage clamps, these may range from a walled clamp (bunker) to a simple stack (field clamp). Walled clamps consist of a permanent structure constructed above ground with three walls. The walls are usually made of concrete, steel or railway sleepers [65] and floors are generally made of concrete with drainage channels to facilitate the collection of effluent. This effluent, due to its high organic content, could pose environmental problems but also energy losses. Maize, grass and cereal silage generally produce little effluent, whereas crops with higher moisture content, such as beets, generate higher amounts of effluent [51]. The effluent has a high energy content so, especially for biogas production it is important to capture and feed this effluent back to the digester [63].

The clamp design plays an important role in silage making. Specifically, the wall slope and height and the exposed faced are two of the critical design factors that affect silage quality as they affect the packing ability. Sloped walls and high walls have been shown to facilitate 
consolidation $[65,66]$. Additionally, by reducing the exposed face area clamp losses are minimized [68]. Hence, clamps should be sized to match the recommended feeding rates shown in Table 3. The importance of reducing the exposed face seems to be well understood by farmers producing silage. In fact, in the study on current UK practices by farmers producing silage [64], the most common change that farmers would implement if they were to re-design their silo, was to build narrower clamps or to install dividing walls to their existing clamps.

The inexpensive alternative to a walled clamps/bunkers are field clamps (unwalled clamps or piles). Field clamps consist of a silage pile covered with plastic. Since there are no walls, the height of these kind of clamps is limited for safety reasons and this means that the required level of compaction often cannot be achieved [65]. Field clamps have higher DM losses than bunkers because the exposed face is much bigger. There is also a higher risk of achieving poor quality silage if the recommended practices are not followed [51].

An alternative to clamps is to use silo bags (e.g., American Ag Bag) or wrapped bales. Wrapped bales and pressed bag silages have created more flexibility in silage making [69]. Various experiments prove that ensiling in bags results in low DM losses due to the rapid exclusion of air [48] Wrapped bales are suitable for small batches [70]. Therefore, they could be an appropriate alternative for small-scale plants. However, even though high quality silage can be made with wrapped bales, fermentation is somewhat restricted relative to fermentation in other silo types [68]. The main disadvantage of both systems is the high storage cost per ton of silage [65]. Additionally, ensiling beet in bales risks poor fermentation and an increase in DM losses because of increased moisture content [65]. However, the development of these systems is ongoing, in order to help them produce more consistent silage and to make them more efficient [69].

A major determinant for silo type used is the volume of silage that is required. Clamps seem to be the best option when considering large quantities of silage. Bags could also be a good option for farmers ensiling around 10,000 tonnes [71]. In the UK AD farmers generally produce much larger volumes of silage than those who grow crops for animal feed and the majority of the AD farmers (92\%) have bunker silos, whilst $75 \%$ of animal feed farmers use bales [64]. However, the literature available to date does not reflect this difference between the sizes of farms and silo types used by farmers producing silage for AD and those producing silage for animal feed. The difference is due to two reasons: firstly, cattle in the UK will generally eat silage during the winter, when they are kept indoors, while AD plants will use silage all year round. Secondly, AD plants generally require more silage per day than the cattle. 
Table 2. Comparison of silo structure types $[65,71]$

\begin{tabular}{|c|c|c|c|c|}
\hline Criteria & Walled Clamp/Bunker & Field Clamp/Pile & Silage/Ag-Bag & Wrapped Bale \\
\hline Construction cost & High & Low & Low & Low \\
\hline Cost/ tonne of storage DM & Low & Low & High & High \\
\hline Flexibility and capacity & $\begin{array}{l}\text { Inflexible storage } \\
\text { Highest capacity }\end{array}$ & Flexibility on pile quantity & $\begin{array}{l}\text { Flexible with store sitting } \\
\text { Capacity can be adjusted } \\
\text { based on yield }\end{array}$ & $\begin{array}{l}\text { Suitable for small batches } \\
\text { Capacity can be adjusted } \\
\text { based on yield }\end{array}$ \\
\hline Footprint & The smallest & Larger than in bunkers & Larger than bunker and pile & The largest \\
\hline Durability & Long lasting & $\begin{array}{l}\text { Better for short storage } \\
\text { periods }\end{array}$ & $\begin{array}{l}\text { Not suitable for storage }>3 \\
\text { years }\end{array}$ & $\begin{array}{l}\text { Not suitable for storage > } \\
12 \text { months }\end{array}$ \\
\hline Suitable crops & All crops & All crops & All crops & $\begin{array}{l}\text { Not suitable for high } \\
\text { moisture crops }\end{array}$ \\
\hline Machinery required & $\begin{array}{l}\text { Conventional farm } \\
\text { equipment }\end{array}$ & $\begin{array}{l}\text { Conventional farm } \\
\text { equipment }\end{array}$ & Specialized equipment & $\begin{array}{l}\text { Conventional farm } \\
\text { equipment }\end{array}$ \\
\hline Compaction achieved & $\begin{array}{l}\text { Good (better with slanted } \\
\text { wall) }\end{array}$ & Lower density than bunkers & $\begin{array}{l}\text { Adequate, but lower than } \\
\text { bunkers }\end{array}$ & Adequate \\
\hline DM losses expected & Higher than bags & The highest & The lowest & Higher than bags \\
\hline $\begin{array}{l}\text { Labour requirements for } \\
\text { filling }\end{array}$ & $\begin{array}{l}\text { More than for bags and } \\
\text { bales }\end{array}$ & $\begin{array}{l}\text { More than for bags and } \\
\text { bales }\end{array}$ & Modest & The least \\
\hline $\begin{array}{l}\text { Exposed surface face at } \\
\text { feeding }\end{array}$ & Large & The largest & The smallest & Small \\
\hline Management issues & Care in filling and packing & $\begin{array}{l}\text { Difficult packing } \\
\text { Good management is } \\
\text { critical }\end{array}$ & $\begin{array}{l}\text { Bags are easy to damage } \\
\text { (vulnerable to spoilage } \\
\text { losses) }\end{array}$ & $\begin{array}{l}\text { Damage can occur when } \\
\text { storing and moving bales } \\
\text { (vulnerable to spoilage } \\
\text { losses) }\end{array}$ \\
\hline
\end{tabular}




\section{Practical implications of this study, Recommendations and Future work}

\subsection{Practical implications}

This review has consolidated current knowledge in the field of silage for AD and confirmed that that the method of quality evaluation for biogas production should be slightly different than for animal feeding and that new process parameters need to be defined. The initial analysis of these parameters include:

1. Dry matter content should be lower (28-40\%) and chopping lengths should be shorter (7$12 \mathrm{~mm}$ ) for AD silage than for conventional silage for biological and technical reasons.

2. Hetero $L A B$ additives are the only conventional additive that are able to reduce energy losses during ensiling.

3. Leachate collection and reuse is a critical for energy loss minimisation because of its high energy content.

4. Storage system for $A D$ is directly related to the size of farm. Clamp/bunker are good for achieving good compaction, not so crucial for AD silage. Cheaper options such as bags can be a good alternative.

5. The use of an oxygen barrier film is recommended to inhibit the growth of microorganisms responsible for aerobic deterioration.

More focused studies are needed to determine specific requirements of $A D$ silage and to determine best-practice for its production and management.To date, available data is largely lacking, and where it is available this is generally from single studies. Consequently, further work is needed to determine the target values for different types of silage for $A D$, and the impact of the various parameters on methane yields.

\subsection{Recommendations for silo management}

Most of the subject matter surrounding the management of silos presumes that the key factors involved are similar to those involved with the management of silage for animal feed. Therefore, many of the important silage management factors focus on getting to the stable face quickly and restricting oxygen exposure at the feed out. The procedures depend on the equipment available and the silo structure type (Table 3).

Filling and compaction: Filling the silo at the recommended DM content and chop length improves compaction and prevents the ingress of air. The expected densities when ensiling at optimal conditions are shown in Table 1 and differ for the two uses. The silo should be filled as rapidly as possible. In large clamps, where the filling process takes several days, the material should be compacted with the progressive wedge technique. In this way the current day material will be 'sealed' by the next day material, thus minimising aerobic deterioration [72].

Sealing: Well-sealed silos help to minimise aerobic losses during storage [72]. In clamps, how well the silo is sealed depends on the cover material used and how it is held in place. The 
standard material used is polyethylene film. However, recent studies on oxygen barrier films [74-76] found that silage sealed with oxygen barrier film have significantly less DM losses in comparison with the same silage covered with polyethylene. Similarly, [73] showed that the oxygen barrier film is a better inhibitor of microorganisms responsible for aerobic deterioration.

Table 3. Silo management practices to minimize energy losses depending on the silo structure (W = Winter, $S=$ Summer) $[74,75]$.

\begin{tabular}{|c|c|c|c|c|}
\hline Process & $\begin{array}{c}\text { Walled } \\
\text { Clamp/Bunker }\end{array}$ & $\begin{array}{c}\text { Field } \\
\text { Clamp/Pile }\end{array}$ & Silage/Ag-Bag & $\begin{array}{c}\text { Wrapped } \\
\text { Bale }\end{array}$ \\
\hline Filling & $\begin{array}{l}\text { Chop at correct } \\
\text { length } \\
\text { Optimal DM } \\
\text { Rapid fill } \\
\text { Progressive wedge } \\
\text { technique }\end{array}$ & $\begin{array}{l}\text { Chop at correct } \\
\text { length } \\
\text { Optimal DM } \\
\text { Rapid fill } \\
\text { Progressive } \\
\text { wedge } \\
\text { technique }\end{array}$ & $\begin{array}{c}\text { Chop at } \\
\text { correct length } \\
\text { Optimal DM } \\
\text { Rapid fill }\end{array}$ & Optimal DM \\
\hline Compaction & $\begin{array}{c}\text { Compress with tractor } \\
\text { during filling }\end{array}$ & $\begin{array}{l}\text { Compress } \\
\text { mechanically } \\
\text { during filling }\end{array}$ & $\begin{array}{l}\text { Set filling } \\
\text { machine for } \\
\text { high } \\
\text { compaction }\end{array}$ & Bale tightly \\
\hline Sealing & $\begin{array}{l}\text { Immediately after } \\
\text { filling } \\
\text { Cover with plastic }\end{array}$ & $\begin{array}{l}\text { Immediately } \\
\text { after filling } \\
\text { Cover with } \\
\text { plastic }\end{array}$ & $\begin{array}{l}\text { While it is } \\
\text { filled }\end{array}$ & $\begin{array}{l}\text { Immediately } \\
\text { after baling }\end{array}$ \\
\hline & $\begin{array}{l}\text { seal ends and sides } \\
\text { carefully }\end{array}$ & $\begin{array}{l}\text { seal ends and } \\
\text { sides carefully }\end{array}$ & $\begin{array}{l}\text { Seal ends } \\
\text { carefully }\end{array}$ & $\begin{array}{c}\text { Wrap or seal } \\
\text { carefully }\end{array}$ \\
\hline & $\begin{array}{c}\text { Check every two } \\
\text { weeks }\end{array}$ & $\begin{array}{c}\text { Check every two } \\
\text { weeks }\end{array}$ & $\begin{array}{l}\text { Check every } \\
\text { two weeks }\end{array}$ & $\begin{array}{l}\text { Check every } \\
\text { two weeks }\end{array}$ \\
\hline Storage & $\begin{array}{l}\text { Seal cracks in wall, } \\
\text { repair holes in plastic } \\
\text { cover }\end{array}$ & $\begin{array}{l}\text { Repair holes in } \\
\text { plastic cover }\end{array}$ & $\begin{array}{c}\text { Repair } \\
\text { damaged bags }\end{array}$ & $\begin{array}{c}\text { Repair } \\
\text { damaged } \\
\text { bags }\end{array}$ \\
\hline Feed out & $\begin{array}{c}10 \mathrm{~cm} / \text { day }(\mathrm{W}) \\
16 \mathrm{~cm} / \text { day }(\mathrm{S})\end{array}$ & $\begin{array}{c}10 \text { cm/day (W) } \\
16 \mathrm{~cm} / \text { day (S) }\end{array}$ & $\begin{array}{c}10 \mathrm{~cm} / \text { day }(\mathrm{W}) \\
16 \mathrm{~cm} / \text { day }(\mathrm{S})\end{array}$ & \\
\hline
\end{tabular}

Feeding out: As soon as the silo is opened for feeding silage will start to deteriorate [72]. The size of the silage structure plays an important role in this phase because it is recommended to remove at least the amount of silage per day shown in Table 3 to minimize deterioration 
in the face exposed to oxygen. A smooth face is also recommended. Hence, the machinery used plays a key role both during the compaction and the feeding.

Special attention also needs to be paid to effluent losses. Maize, grass and cereal silage produce little effluent, but because of its moisture content, the effluent from beets runs off rapidly [51]. This effluent has a high energy content so it is important to capture it and feed the digester with it [63].

\subsection{Future work}

\subsubsection{Quality Requirements of Silage for $A D$}

More research is necessary to understand the effects of DM losses and a focus on the compensatory relationship between DM losses and methane enhancement. This may improve the crop's methane yield per hectare [34], which is a critical factor for silage productivity, and the sustainability of silage for $A D$, since land use requirements for crop growth could be reduced. Further investigation and experimentation into optimal chop lengths is also strongly recommended, as suggested in [6] and [62]. Particular emphasis should be on determining the relationship between increased methane yields and increased costs of shorter chop lengths.

\subsubsection{Additives for $A D$}

Very little research has been carried out on the development of specific additives for ensiling of biogas feedstock, away from the considerations of animal feed. Specifically, the formulation of additives consisting of complex mixtures of homo and hetero $L A B$ as well as enzymes or bacteria, as suggested by [48] should be considered. Additionally, the use of acidic additives, such as formic and acetic acids, as chemical preservatives should also be explored. To date, these have been largely ignored, since many are inappropriate for animal feed due to decreased carbohydrate preservation and DM losses $[15,40]$. Yet, some acidic pretreatments have been shown to improve biogas production as a consequence of cellulosic material breakdown and increasing the accessible surface area of the crop material [15]. Therefore, although such acidic additives are likely to be associated with DM losses, these may be compensated for by improved crop digestibility.

\subsubsection{Silage Production and Management Practices}

Silage production and management practices are some of the most important factors that may influence energy losses [65]. To date, it is largely considered that the key factors involved in silage destined for AD and animal feed are similar. Yet, it is clearly evident that different silage management practices are likely to be required. Therefore, future research should also concentrate on the investigation of differences in silage production and management practices of farmers with crops destined for $A D$ and animal feed. 
One of the key contributors to such expected differences in requirements is due to differences in the type of operations. In addition to the disparities in silo size, the majority of AD farmers (72\%) reported using more than one crop when ensiling, whilst only $25 \%$ of animal feed farmers employed such practices [60]. Therefore, conditions for mixed silage, in addition to single crop silage, should also be identified, yet these have not been taken into account to date. Of concern is that the majority of farmers in [60] have indicated that they would not consider investing in training in silage management. Yet at the same time, poor silage management was one of the main causes of energy losses during the silage making process, together with bad weather conditions during ensiling [60].

The differences between the key considerations for AD farmers and dairy farmers provide further support to the idea stated in [38] and [34] that the method of quality evaluation should be slightly different than for animal feeding. However, without the necessary data that defines the degree of dependence between quality parameters and methane formation, it is not possible to provide conclusive indications for optimal silage production and management practices for AD.

\subsubsection{Silage management for agricultural residue to $A D$}

Energy crops produced for AD have attracted a lot of scientific and societal discussions that relates to competition with feed cropping, food production and environmental efficiency. Thus, ensiling agricultural residues for $A D$ in place of whole crops is now considered to address these controversies and bring about a concomitant nutrient cycle maintenance and the management of residues [2]. Since residues are of varying types or quality and accrue at different locations, amounts and time, ensiling is an essential tool for its preservation and pre-treatment for an improved feedstock quality that is sustainable [2]. Table 4 gives a list of ensiled residues and their sources.

For a successful residue silage production, it is important to note the different physical structure and compositions of the residues to be employed in the process [81]. For instance wilting is an important pre-treatment for high moisture residues like sweet potatoes vines and grass chippings, whilst tightly packed residues like maize stover and cereal straws require slight wetting. Prior to ensiling, pre-treatments, like fine chopping, use of additive and codigestion are required for residues with low water soluble carbohydrates (WSC) in other to increase their DM. For instance finely chopped cereal straw can be mixed with chopped vines before ensiling [80]. Protein rich feeds such as fish wastes, should be co-ensiled with spent grain or fruit wastes such as watermelon residues which has been reported by [85] to be energy rich.. Also, molasses can be applied as additives to any residue silage treatment to achieve a high quality silage [81].

There are a number of foreseeable challenges with the application of silage residues to $A D$, since residues are from a broad range of feedstocks that are diverse in composition and structure [2]. In addition, the supply chain is not yet sustainable as residues accrue in small 
amounts and are decentralized and their collections may be challenging both logistically and monetarily. Also of concern is that some residues are not readily biodegradable and may contain high levels of toxin or be contaminated with impurities and pathogens $[2,86]$.

Table 4: List of ensiled residues and their sources

\begin{tabular}{|c|c|c|}
\hline Residue source & Examples & References \\
\hline Landscape management & $\begin{array}{l}\text { grass clippings, or yard trimmings, pruned } \\
\text { branches, shaded tree leaves }\end{array}$ & {$[2,77,78]$} \\
\hline Crop production & $\begin{array}{l}\text { maize stover (that include; stalks, leaves, } \\
\text { husks, and cobs), sweet potatoes vines, } \\
\text { cassava leaves and cereal straw }\end{array}$ & {$[79,80]$} \\
\hline $\begin{array}{l}\text { Agro-industrial by- } \\
\text { products }\end{array}$ & $\begin{array}{l}\text { spent grain, fish wastes, molasses, fruits } \\
\text { and vegetable wastes }\end{array}$ & {$[81,82]$} \\
\hline $\begin{array}{l}\text { De-weeding and } \\
\text { maintenance of } \\
\text { waterways }\end{array}$ & aquatic plants and algae biomass & {$[83,84]$} \\
\hline
\end{tabular}

\section{Conclusions}

The employment of silage for use in $A D$ is anticipated to keep increasing in the coming years and decades, as increasing efforts to meet renewable energy targets are made. To date, silage for $A D$ is largely treated as silage for animal feed by many operators. However, although the principles of ensiling remain the same, some specific differences do exist e.g. acetic acid could be present in higher levels in silage for $A D$ as it enhances methane formation. Overall, the moisture content, chop length, additive usage, silo type and silo management have been identified to be the factors that have the greatest impact upon methane yields. In particular, conventional additives, except heterolactic bacteria, reduce DM losses but have little effect on methane yield. Crops for AD use should be chopped to shorter lengths and ensiled at a lower dry matter content than the ones for animal feeding. Finally, management is the most important factor influencing DM and energy losses, especially during filling and feed out.

The specific recognition of the differences between the use of silage for AD and crops is of particular importance as it will allow for best-practice in and improve bioenergy production and sustainability. 


\section{Acknowledgements}

This work was supported by the Bio-Thermal Renewable Energy Demonstrator (Grant no ERDF/12/057) and Bock UK.

\section{References}

1. S. Y. Balaman Decision making for biomass-based production chains: the basic concepts and methodologies (2019) Frist ed. Academic Press, Cambridge, Massachusetts, pp 1-23.

2. S. Theuerl, C.V. Herrmann, M. Heiermann, P. Grundmann, N. Landwehr, U. Kreidenweis, A. Prochnow The future of agricultural biogas plant in Germany: A vision. Energies. 12 (2019), pp 396-428.

3. ADBA, CLA, NFU and REA, The case for crop feedstocks in Anaerobic Digestion, UK., https://adbioresources.org/wp-content/uploads/2012/09/120730-PGC-BriefingDoc.pdf?_ga=2.247406733.806477575.1511777358-2130278741.1491922701 [accessed 28/08/2020] (2011).

4. C. Gisse'n, T. Prade, E. Kreuger, I.A. Nges, H. Rosenqvist, S. Svensson, M. Lantz, J.E. Mattsson, P. Bo"rjesson, L. Bjo"rnsson Comparing energy crops for biogas production e Yields, energy input and costs in cultivation using digestate and mineral fertilisation. Biomass and Bioenergy, 64 (2014), 199-210.

5. G. Borreani, E. Tabacco, R.J. Schmidt, B.J. Holmes, R.E. Muck Silage review: Factors affecting dry matter and quality losses in silages. J. Dairy Sci., 101 (2018), pp 3952-3979.

6. A. Prochnow, M. Heiermann, M. Plochl, B. Linke, C. Idler, T. Amon, P.J. Hobbs Bioenergy from permanent grassland--a review: 1. Biogas. Bioresour. Technol., 100 (2009), pp 49314944.

7. R.T. Franco, P. Buffière, R. Bayard Ensiling for biogas production: Critical parameters. Biomass and Bioenergy, 94 (2016), pp 94-104.

8. Burgess J, Witheford S. KWS UK Ltd Biogas in practice guide http://www.adbiogas.co.uk/wp-content/uploads/2012/08/Biogas-in-Practice Guide.pdf [accessed 28/08/2020] (2014).

9. F. Mayer, P.A. Gerin, A. Noo, G. Foucart, J. Flammang, S. Lemaigre, G. Sinnaeve, P. Dardenne, P. Delfosse, P. Assessment of factors influencing the biomethane yield of maize silages. Bioresour. Technol., 153 (2014), pp 260-268.

10. M.P.M.L.B. Heiermann, H. Schelle, C. Herrmann Biogas Crops-Part I: Specifications and Suitability of field crops for anaerobic digestion. Agric. Eng. International: CIGR EJournal. 11 (2009), pp 1087-1104.

11. C. Herrmann, M. Heiermann, C. Idler Effects of ensiling, silage additives and storage period on methane formation of biogas crops. Bioresour. Technol., 102(2011), pp 51535161.

12. C. Strauß, A. Vetter, M. Dickeduisberg, A. Von Felde Energy from Organic Materials (Biomass), in: Kaltschmitt, M. (Ed.), Energy. Springer, New York, NY, (2019) pp. 113-164.

13. P. Kalač The required characteristics of ensiled crops used as a feedstock for biogas production: a review. J. Agrobiol., 28 (2011), pp 85-96.

14. P. Tsapekos Enhancing biogas production from recalcitrant lignocellulosic residue. https://orbit.dtu.dk/files/128540838/WWW_version.pdf [accessed 28/10/2019] (2017). 
15. A. Pakarinen, P Maijala, S. Jaakkola, F.L. Stoddard, M. Kymalainen, L. Viikari Evaluation of preservation methods for improving biogas production and enzymatic conversion yields of annual crops. Biotechnol. Biofuels, 4 (2011), pp 20-33.

16. I. Sakhawat The effect of silage quality on gross energy losses. https://pdfs.semanticscholar.org/9283/9e8a091b19b300b8d6191697fee4c1288b49.pdf [accessed 28/08/2020] (2011).

17. R. Lemus Understanding Silage Making Process and Utilization. Forage news, 3 (2010), pp 1-4.

18. I. Melkamu, T. Birhan Silage Additives: Review. Open J. Appl. Sci., 4 (2013), 10.4236/ojapps.2014.45026.

19. T.C. da Silva, L.D. da Silva, E.M. Santos, J.S. Oliveira Importance of the Fermentation to Produce High-Quality Silage. Ferment. Process., (2017), https://doi.org/10.5772/64887

20. H. Guan, Y. Shuai, Y. Yan, Q. Ran, X. Wang, D. Li . Microbial community and fermentation dynamics of corn silage prepared with heat-resistant lactic acid bacteria in a hot environment. Microorganisms, 8.719 (2020) https://doi.org/10.3390/microorganisms8050719

21. J. Heguy, N. Silva Understanding the ensiling process can help you reach your silage feeding goals https://www.progressivedairycanada.com/topics/feednutrition/understanding-ensiling-process-can-aid-silage-feeding-goals [accessed 28/08/2020] (2010).

22. J. McEniry, P. O'Kiely Anaerobic methane production from five common grassland species at sequential stages of maturity. Bioresour. Technol. 127 (2013), pp 143-150.

23. S. Ohl, B. Wienforth, A. Herrmann, K. Sieling, F. Taube, H. Kage, E. Hartung The influence of ensiling on substrate specific methane yield and methane yield per hectare.

Proceedings of the XVI International Silage Conference, Hameenlinna, Finland, (2012) pp. 454-456.

24. K.I. Suhr, C.O. Letelier-Gordo, I. Lund Anaerobic digestion of solid waste in RAS: Effect of reactor type on the biochemical acidogenic potential (BAP) and assessment of the biochemical methane potential (BMP) by a batch assay. Aquacultural Eng., 443 (2015), pp 65-71.

25. E. Kreuger, I.A. Nges, L. Bjornsson. Ensiling of crops for biogas production: effects on methane yield and total solids determination. Biotechnol Biofuels, 4 (2011), pp 4-44.

26. G. Strazzera, F. Battista, N.H. Garcia, N. Frison, D. Bolzonella, D. Volatile fatty acids production from food wastes for biorefinery platforms: A review. J. of Environ. Mgt., 226 (2018), pp 278-288.

27. T. Amon, B. Amon, V. Kryvoruchko,, A. Machmuller, K. Hopfner-Sixt, V. Bodiroza, R. Hrbek, J. Friedel, E. Potsch, H. Wagentristl, M. Schreiner, W. Zollitsch Methane production through anaerobic digestion of various energy crops grown in sustainable crop rotations. Bioresour. Technol., 98 (2007), pp 3204-3212.

28. A. Chiumenti, A. Pezzuolo, D. Boscaro, F. da Borso Exploitation of Mowed Grass from Green Areas by Means of Anaerobic Digestion: Effects of Grass Conservation Methods (Drying and Ensiling) on Biogas and Biomethane Yield. Energies, 12 (2019), pp 3244-3255.

29. M. Neureiter, J.T.P. dos Santos, C.P. Lopez, H. Pichler, R. Kirchmayr, R. Braun Effect of silage preparation on methane yields from whole crop maize silages. Proceedings of the 4th international symposium on anaerobic digestion of solid waste, Copenhagen, Denmark, (2005), pp. 109-115 
30. O. Pakarinen, A. Lehtomaki, S. Rissanen, J. Rintala Storing energy crops for methane production: effects of solids content and biological additive. Bioresour. Technol. 99 (2008), pp 7074-7082.

31. F. Weissbach Gas production potential of fresh and ensiled sugar beets in biogas production. Landtechnik, 64 (2009), pp 394-397.

32. C. Whittaker, J. Hunt, T. Misselbrook, I. Shield How well does Miscanthus ensile for use in an anaerobic digestion plant? Biomass and Bioenergy, 88 (2016), pp 24-34.

33. A. Lehtomäki Biogas production from energy crops and crop residues. University of Jyväskylä, Finland https://jyx.jyu.fi/bitstream/handle/123456789/13152/9513925595.pdf?sequen [accessed 28/08/2020] (2006).

34. M. Ploechl, H. Zacharias, C. Herrmann, M. Heiermann, A. Prochnow Influence of silage additives on methane yield and economic performance of selected feedstock. Agric. Eng. Intl: CIGR EJournal, 11 (2009), pp 1123.

35. T. Prade, S. Svensson, T. Hörndahl, E. Kreuger Impact of Harvest Date and Cutting Length of Grass Ley and Whole-Crop Cereals on Methane Yield and Economic Viability as Feedstock for Biogas Vehicle Fuel Production. Bioenergy Research, 12 (2019), pp 137149.

36. B. Santoso, T.W. Widayati, B.T. Hariadi The Fermentation Quality and in vitro Nutrient Digestibility of Agricultural Waste Based-Complete Feed Silage with Different Composition of Oil Palm Frond and Rice Crop Residue. Adv. Anim. Vet. Sci., 7 (2019), pp 621-628.

37. M. Mrůzek An analysis of biogas production from grass silage as dependent upon feed quality. Inżynieria Rolnicza., 15 (2011), pp 107-114.

38. R.P. Egg, Feedstock storage, handling and processing. Biomass and Bioenergy, 5(1993), pp 71-94.

39. D. Gallegos, H. Wedwitschka, L. Moeller, S. Weinrich, A. Zehnsdorf, M. Nelles, W. Stinner Mixed silage of Elodea and wheat straw as a substrate for energy production in anaerobic digestion plants. Energ. Sust. Society., 8(2018), pp 1-8.

40. C. Idler, M. Heckel, C. Herrmann, M. Heiermann Influence of biological additives in grass silages on the biogas yield. Res Pap IAg Eng LU Ag 39(2007), pp 69-82

41. M. Chahine, T. Fife, G. Shewmaker Target values for corn silage. Proceedings of the Idaho alfalfa and forage conference, (2009), pp 1-5.

42. P. Nu Wu, L. Li, J. Jiang, Y. Sun, Z. Yuan, X. Feng, Y. Guo Effects of fermentative and nonfermentative additives on silage quality and anaerobic digestion performance of Pennisetum purpureum. Biores. Technol., 297 (2020), pp.

43. X. Zhao, L. Jinhuan, L. Jingjing, F. Yang, Z. Wanbin, Y. Zhu, Y. Xufeng, H. Yuegao, C. Zongjun, W. Xiaofen Effect of ensiling and silage additives on biogas production and microbial community dynamics during anaerobic digestion of switchgrass, Biores. Technol., 241 (2017), pp. 349-359.

44. X. Cui, H. Sun, M. Sobhi, X. Ju, J. Guo, R. Dong Butyric Acid Fermentation during Ensiling of Wilted Maize Stover for Efficient Methane Production. ACS Sust. Chem. Eng., 8(17), (2020) pp. 6713-6721.

45. J. McEniry, E. Allen, J.D. Murphy, P. O'Kiely Grass for biogas production: The impact of silage fermentation characteristics on methane yield in two contrasting biomethane potential test systems. Ren. Energy, 63 (2014), pp 524-530. 
46. P.S. Calabrò, F. Fazzino, R. Sidari, D.A. Zema Optimization of orange peel waste ensiling for sustainable anaerobic digestion. Ren. En., 154 (2020), pp. 849-862.

47. A.S. Nizami, N.E. Korres, J.D. Murphy Review of the integrated process for the production of grass biomethane. Environ. Sci. Technol., 43 (2009), pp 8496-8508.

48. H. Vervaeren, K. Hostyn, G. Ghekiere, B. Willems Biological ensilage additives as pretreatment for maize to increase the biogas production. Renew. Energy, 35 (2010), pp. 2089-2093.

49. M. Kaplan Determination of Silage Characteristics and Nutritional Values of Some Triticale Genotypes. Türk Tarım ve Doğa Bilimleri Dergisi, 1 (2014), pp 102-107.

50. F. Gülzow Guide to biogas from production to use https://mediathek.fnr.de/media/downloadable/files/samples/g/u/guide biogas engl 20 12.pdf [accessed 28/10/2019] (2012).

51. R. Norell, M. Chachine, P. Beard Ensiling pressed beet pulp https://www.extension.uidaho.edu/publishing/pdf/BUL/BUL0848.pdf [accessed 28/10/2019] (2007).

52. H. Nussbaum Effects of silage additives based on homo- or heterofermentative lactic acid bacteria on methane yields in the biogas processing. Proceedings of the XVI International Silage Conference, Hämeenlinna, Finland. (2012), pp. 452-453.

53. C. Herrmann, M. Heiermann, C. Idler Improving aerobic stability and biogas production of maize silage using silage additives. Bioresour. Technol., 197 (2015), pp 393-403.

54. S. Ahmed, D. Einfalt, M. Kazda Co-Digestion of Sugar Beet Silage Increases Biogas Yield from Fibrous Substrates. BioMed Res. Int., (2016). ID 2147513. doi:10.1155/2016/2147513

55. DOW Pre-wilting and estimating dry matter content of grass silage http://msdssearch.dow.com/PublishedLiteratureDOWCOM/dh_0064/0901b8038006406 b.pdf?filepath=silage/pdfs/noreg/254-15901.pdf\&fromPage=GetDoc [accessed 28/10/2019] (2008).

56. GrainSeed Ltd. High output biogas seed options https://www.horizonseeds.com/wpcontent/uploads/2017/03/Biogas-Leaflet-2017.pdf [accessed 28/10/2019] (2014).

57. F. Mickan Harvesting forage cereals http://www.depi.vic.gov.au/agriculture-andfood/grains-and-other-crops/crop-production/harvesting-forage-cereals [accessed 28/08/2020] (2008).

58. R. Lackey Sugar beet as a feed ingredient Sugar Beets as a Feed Ingredient [accessed 28/08/2020] (2013).

59. BGS Silage decision factsheet - Chop length https://www.britishgrassland.com/system/files/Chop\%20length\%20factsheet.pdf [accessed 28/08/2020] (2007).

60. P. McDonald The biochemistry of silage John Wiley \& Sons, Ltd., Chichester (UK), (1981)

61. J. Barnhill, L. Greenhalgh, C. Israelsen, M. Pace, J. and Gale Chopping and Storing Quality Corn Silage, AG/Farmland/2009-02pr https://digitalcommons.usu.edu/cgi/viewcontent.cgi?article=1144\&context=extension c urall\&httpsredir=1\&referer= [accessed 28/08/2020] (2009).

62. C. Herrmann Particle size reduction during harvesting of crop feedstock for biogas production: effects on ensiling process and methane yields. BioEnergy Res., 5(2012), pp 926- 936. 
63. A. Wagner, H. Auerbach, C. Herbes Preservation of sugar beets for biogas production. Stuttgart-Hohenheim (2011).

64. L. Ortega Rodriguez, C. Fenech, R. Villa Development of a best practice guide for silage systems in anaerobic digestion.

https://cran.ent.sirsidynix.net.uk/client/en_GB/knl/search/results/?ln=en_GB\&q=Develo pment+of+a+best+practice+guide+for+silage+systems+in+anaerobic+digestion $\& r w=0$ (2014).

65. A.G. Kaiser, J. Piltz, H. Burns, N. Griffiths Top fodder successful silage, second ed. Dairy Australian and New South Wales Department of Primary Industries, Australia (2004).

66. ACP Ltd., Anaerobic digester silage and clamp design, https://www.edie.net/28215/pr/Anaerobic-Digester-Silage-and-Clamp-Design/24667), [accessed 28/08/2020] (2013).

67. L. Hartley Handy hints: Six top tips on making good quality silage http://www.farmersguardian.com/home/livestock/livestock-features/handy-hints-sixtop-tips-on-making-good-quality-silage/65180.article [accessed 28/08/2020] (2014).

68. R.E. Muck Fermentation Characteristics of Round-Bale Silages. http://agrilifecdn.tamu.edu/spfcic/files/2013/02/muck.pdf [accessed 28/08/2020] (2006) pp 1-11.

69. T.F. Bernardes Technological innovations in silage production and utilization Revista Brasileira de Saúde e Produção Animal., 13 (2012), pp 629-641.

70. L. Hopwood Farm-Scale Anaerobic Digestion Plant Efficiency; National Non-Food Crops Centre (NNFCC) https://www.nnfcc.co.uk/files/mydocs/Farm-Scale-Anaerobic-DigestionPlant-Efficiency-NNFCC-11-015.pdf [accessed 28/08/2020] (2011).

71. A. Wagner, U. Weber Secure storage of energy feedstock: Biomass in silage bags, BAG Budissa Agroservice ed, Ag-Bag, https://www.agbag.co.uk/services/ad-feedstockstorage/ [accessed 28/08/2020] (2014).

72. J. Moran Tropical dairy farming: feeding management for small holder dairy farmers in the humid tropics. Landlinks Press (2005).

73. S. Orosz, J.M. Wilkinson, S. Wigley, Z. Bíró, J. Galló Microbial status, aerobic stability and fermentation of maize silage sealed with an oxygen barrier film or standard polyethylene film. Agric. Food Sci., 22 (2013), pp 182-188.

74. C.M. Jones From harvest to feed: Understanding silage management http://pss.uvm.edu/pdpforage/Materials/CuttingMgt/From Harvest to Feed Understa nding Silage management PennState.pdf [accessed 28/08/2020] (2004)

75. B.J. Holmes, R.E. Muck Preventing Silage Storage Losses. https://fyi.extension.wisc.edu/forage/files/2014/01/prevent-silage-storage7.pdf [accessed 28/08/2020] (2000).

76. G. Borreani, E. Tabacco, L. Cavallarin A new oxygen barrier film reduces aerobic deterioration in farm-scale corn silage J. Dairy Sci., 90 (2007), pp 4701-4706.

77. R. Bedoić, L. Čuček, B. Ćosić, D. Krajnc, G. Smoljanić, Z. Kravanja, D. Ljubas, T. Pukšec, N. Duić Green biomass to biogas - A study on anaerobic digestion of residue grass. J. Clean. Prod. 213 (2019), pp 700-709.

78. H. Himanshu, J.D. Murphy, J. Grant, P. O'Kiely Antagonistic effects on biogas and methane output when co-digesting cattle and pig slurries with grass silage in in vitro batch anaerobic digestion. Biomass and Bioenergy, 109 (2018), pp 190-198. 
79. G. Tengyun Review: Treatment and utilization of crop straw and stover in China Livestock Research for Rural Development, 12 (2000) http://www.Irrd.org/Irrd12/1/gao121.htm [accessed 28/08/2020]

80. L. Jianxin, G. Jun Ensiling crop residues http://www.fao.org/3/y1936e/y1936e08.htm [accessed 28/08/2020] (2001)

81. FAO http://www.fao.org/ag/againfo/themes/documents/PUB6/P622.htm [accessed 28/08/2020] (2007).

82. A. Gholami-Yangije, R. Pirmohammadi, H. Khalilvandi-Behroozyar The potential of sunflower (Helianthus annuus) residues silage as a forage source in mohabadi dairy goats. Vet. Res. Forum, 10 (2019), pp 59-65.

83. C. Herbes, V. Brummer, S. Roth, M. Röhl. Using aquatic plant biomass from de-weeding in biogas processes-an economically viable option? Energy. Sustain. Soc., 8 (2018).

84. J.J. Milledge, B.V. Nielsen, S. Maneein, P.J. Harvey A brief review of anaerobic digestion of algae for BioEnergy. Energies, 12 (2019), pp 1-22.

85. A.O. Chinwendu, B.C. Akin-Osanaiye, E. B. Asikong, E.U. Okon The potential of biogas production from fruit wastes (Watermelon, Mango and Pawpaw) World J. Adv. Res. Rev. 01(03), (2019), pp 052-065M. Köttner, A. Kaiser, M.V. Avendaňo Dry fermentation biogas technology - practical approach for closed loop sanitation, waste stabilisation and nutrient recovery, 2nd Intrnational Symposium on Ecological Sanitation, https://sswm.info/sites/default/files/reference attachments/KOETTNER\%20et\%20al\%20 2003\%20Dry\%20fermentation\%20biogas\%20technology.pdf [accessed 28/08/2020] (2003) 